\title{
Spelling Errors in Thai Made by Chinese Students Learning Thai as a Foreign Language
}

\author{
Peng Hou (เพ่ง หุ่ย) \\ Lecturer, Department of Thai Language, Faculty of Oriental Languages and \\ Cultures, Xi'an International Studies University, Xi'an, China \\ xisuhoupeng@163.com
}

\begin{abstract}
When learning a foreign language, it is important to learn how to spell accurately as it is crucial for communication. To spell Thai language accurately is challenging for both native and foreign learners of Thai. However, studies that address spelling errors made by foreign learners of Thai are rare. The purpose of this paper is to analyze patterns and causes behind spelling errors made by Chinese students learning Thai as a foreign language. Data was taken from thirty Chinese students who took part in a Thai language composition writing and dictation task. The results suggest that the main spelling problem for Chinese students is spelling Thai vowels $(37.5 \%)$, followed by initial consonants $(20.7 \%)$, final consonants $(20.4 \%)$, unpronounced letters (18.0\%), tone markers $(2.2 \%)$, and others $(1.2 \%)$. In terms of underlying causes of spelling errors, irregularities in Thai language and interference from Chinese phonology are the two main causes for their spelling errors. Moreover, carelessness, differences between the Chinese and Thai writing systems, and influence from Thai native speakers also account for some of the spelling errors produced among the Chinese students.
\end{abstract}

\section{Keywords}

spelling errors in Thai - foreign language learning - language transfer 
บทคัดย่อ

ข้อผิดพลาดด้านการสะกดคำไทยของนักศึกษาจีนที่เรียนภาษาไทยเป็นภาษาต่างประเทศ

การเรียนรู้วิธีการสะกดคำที่ถูกต้องมีความสำคัญอย่างยิ่งในการเรียนภาษาต่างประเทศเนื่องจากการ สะกดที่ถูกต้องเป็นพื้นฐานของการสื่อสารอย่างมีประสิทธิภาพการสะกดคำภาษาไทยเป็นสิ่งท้าทาย สำหรับเจ้าของภาษาและผู้เรียนชาวต่างประเทศ อย่างไรก็ตาม การศึกษาที่เกี่ยวข้องกับข้อผิดพลาด ด้านการสะกดภาษาไทยของผู้เรียนต่างประเทศนั้นยังมีอยู่น้อยและไม่ครบถ้วน ดังนั้น งานชิ้นนี้ จึงมีจุดประสงค์ที่จะวิเคราะห์รูปแบบและสาเหตุของข้อผิดพลาดด้านการสะกดคำไทยของนักศึกษา จีนที่เรียนภาษาไทยเป็นภาษาต่างประเทศ ข้อมูลที่ใช้ในการวิเคราะห์มาจากการเขียนบทความ และการเขียนตามคำบอกของนักศึกษาจีน จำนวน 30 คนที่เรียนภาษาไทยเป็นภาษาต่างประเทศ ผลการวิเคราะห์พบว่าปัญหาหลักของนักศึกษาจีนคือการสะกดสระไทย $(37.5 \%)$ รองมาคือ การสะกดพยัญชนะต้น $(20.7 \%)$ พยัญชนะท้าย $(20.4 \%)$ ตัวอักษรที่ไม่ออกเสียง $(18.0 \%)$ วรรณยุกต์ $(2.2 \%)$ และข้อผิดพลาดอื่น ๆ $(1.2 \%)$ ผลวิจัยยังพบว่าความสลับซับซ้อนของภาษาไทยและการ แทรกแซงจากระบบเสียงของภาษาจีนเป็นสาเหตุหลักสองประการที่ทำให้นักศึกษาจีนสะกดคำไทย ผิดพลาดนอกจากนี้ยังมีข้อผิดพลาดจำนวนเล็กน้อยเกิดจากความประมาทในการเขียนความแตกต่าง ระหว่างระบบการเขียนของภาษาจีนกับภาษาไทย และการเลียนแบบวิธีการใช้คำของเจ้าของ ภาษาไทย

\section{$1 \quad$ Introduction}

In the field of foreign language learning, the role of spelling has been debated for a long time. Some regard it as a sub-skill of writing and allocate it with limited attention. However, more scholars and researchers have realized the importance of spelling in foreign language learning. Brosh (2015: 585) stated that spelling is central to reading and writing. Correct spelling is considered as the, "ticket to the literacy club, the heir to the traditions and scholarly world of print" (Bean and Bouffler 1987: 67). Whereas spelling errors are strongly criticized since they always convey wrong information and sometimes can be obstacles for effective communication (Alhaisoni, Al-Zuoud, and Gaudel 2015: 185).

Due to the important role of spelling, scholars and researchers with different academic backgrounds have started to pay more attention to it. Even so, related studies are still in their infancy. Data in spelling acquisition from languages other than English are quite scarce due to the international dominance of English (Dich 2011: 3), as more than 950 million people hold English as a second language and correct spelling in English is definitely needed when it is used as a lingua franca (Saville-Troike 2006). Researchers have studied extensively spelling errors in English made by students of various native languages, including: Arabic, Japanese, African American, Korean, and etc., (Mahmoud 2013; Gunion 2012; Treiman and Bowman 2015; Kim 2001). Findings of those studies point in the same direction, which is that spelling errors in foreign 
languages are mainly brought about by two causes: one is the target language itself because of learners' incomplete mastery of foreign language rules, the other involves interference from learners' native languages. However, this conclusion has not been proven in spelling errors in languages other than English.

Thai is one such language which has received insufficient attention in L2 spelling research. Actually, the distinctive writing system of Thai makes it an interesting case to study. Winskel and Iemwanthong (2009: 1022) pointed out that, "Thai has an alphabetic script, which also shares properties with syllable scripts, as it has implicit vowels for some consonants." Moreover, more and more foreigners have started to learn Thai as a foreign language due to the development of Thailand and the practicability of the Thai language (Plaengson 2017: 17). However, studies related to foreigners' spelling errors in Thai are particularly rare.

The present study aims to fill this gap by focusing on spelling errors made by Chinese students learning Thai as a foreign language. The impetus for studying Chinese L2 learners of Thai is twofold. The first reason for selecting Chinese students is that there is presently a "Thai craze" in China. As reported by CCTV (China Central Television), the number of the universities establishing a Thai language program has already reached over fifty by the year of 2017. Thai is becoming one of the most popular foreign languages among Chinese students, especially students from southwestern China. The second reason is that the Thai language has an alphabetic writing system, whereas Chinese characters represent units of meaning rather than units of sounds. Because of the great differences between the Chinese and Thai languages, spelling errors in Thai made by Chinese students were selected as the research subject.

2

Method

\subsection{Participants}

Participants of the present study were composed of thirty Chinese students (nine males and twenty-one females) who majored in Thai language at Xi'an International Studies University. Their age ranged from 20 to 22 years old. Chinese and their dialects were the dominant languages in their daily communication, and Thai was a foreign language for them. All of the students were roughly homogeneous in terms of Thai language exposure and educational backgrounds.

\subsection{Data Collection}

In order to collect spelling errors from the participants, two instruments were utilized. Firstly, the participants were requested to write a composition of 
approximately $100-150$ words in Thai within twenty minutes. The topic of the composition was "My country." They were reminded not to use any fancy scripts ${ }^{1}$ and try to make the composition clear and readable. Second, a sixtyword dictation task was conducted among the participants. Each word had a corresponding sentence to make its meaning clear. All the sentences were selected either from the Thailand National Corpus (TNC) or the Thai-English Electronic Dictionary Lexitron. All of the participants accomplished the two tasks independently and without any help from electronic devices during the writing tasks.

\subsection{Data Analysis}

All of the words that deviated from the spelling in the Royal Institute Dictionary (2011) were identified as spelling errors. Two dimensions were taken into consideration when classifying all the spelling errors. The first dimension was based on the phonological features of the Thai language: errors in vowel letters, initial consonant letters, final consonant letters, unpronounced letters, and tone markers. Another dimension was what happened to the misspelled letters, which was categorized into substitution, omission, and insertion (Ellis 1994: 56):

1) Substitution: selecting incorrect elements.

2) Omission: leaving out required elements.

3) Insertion: adding unnecessary elements.

Each word written by the participants was scrutinized for spelling errors. The frequency counting was based on tokens. Each error was recorded as one occurrence. For example, * <กงศูล $>$ for <กงสุล> /koysǔn/ "consul" was counted as two occurrences. One was categorized into spelling errors in substitution of vowel letters because the speller substituted $<_{v}>/ \mathrm{u}_{\mathrm{i}} /$ for $<_{\mathrm{q}}>/ \mathrm{u} /$, the other was classified into substitution of initial consonant letters because the speller substituted $\langle$ ศ $>/ \mathrm{s} /$ for $\langle$ ส $>/ \mathrm{s} /$. The same exact error was counted again as one occurrence. In other words, occurrences of errors were counted no matter whether they repeated or not. For example, eight students omitted $<-$ ะ $>$ /a/ in the word <สะดวก> /sàdùak/ "convenient," then eight occurrences were counted and classified into the type of omission of vowel letters.

1 The term "fancy scripts" in this paper refers to scribbled handwritings of some students. In practice, some students' handwritings are too scribbled to read and it might cause problems in recognizing what they write in the study. Because of this, participants in this study were reminded not to use "fancy scripts" in their writing and were asked to make their handwriting as legible as possible. 


\section{$3 \quad$ Findings}

\subsection{Patterns of Spelling Errors in Thai made by Chinese Students}

In total, 859 spelling errors were found. All of the spelling errors were first categorized into five types with respect to phonological features of Thai words namely: errors in vowel letters, initial consonant letters, final consonant letters, unpronounced letters, and tone markers. Ten misspelled words could not be grouped into the five categories, so they will be discussed separately. The frequency of occurrence of each pattern is shown in Table 1.

The findings reveal that the biggest difficulty for Chinese students is Thai vowel spelling. Initial consonants and final consonants seem to be equally difficult for them, which account for 20.7 percent and 20.4 percent respectively. Another 18 percent of the errors were grouped as errors in unpronounced letters. On the other hand, the errors regarding tone markers were much rarer (only about two percent).

Classified in another dimension, each pattern of errors mentioned in Table 1 was further divided into substitution, omission, insertion. Thus, the errors are labeled in the following sections as substitution, omission, and insertion reflecting how the misspelled words were written.

\subsubsection{Spelling Errors in Vowel Letters}

In total, 322 spelling errors were found in vowel letters, as shown in Table 2. A predominant percentage (79.5 percent) of the spelling errors falls into

TABLE 1 Patterns of spelling errors classified by phonological features

\begin{tabular}{lccl}
\hline Patterns of spelling errors & Frequency & Percentage & Participants $^{2}$ \\
\hline Vowel letters & 322 & $37 \cdot 5 \%$ & 30 \\
Initial consonant letters & 178 & $20.7 \%$ & 30 \\
Final consonant letters & 175 & $20.4 \%$ & 30 \\
Unpronounced letters & 155 & $18.0 \%$ & 30 \\
Tone markers & 19 & $2.2 \%$ & 11 \\
Others & 10 & $1.2 \%$ & 10 \\
total & 859 & $100 \%$ & 30 \\
& & &
\end{tabular}

2 Participants mean the number of students who made spelling errors. 
TABLE 2 Spelling errors in vowel letters classified by how vowel letters were misspelled

\section{Patterns of spelling errors Frequency Percentage Participants}

\begin{tabular}{lrrr}
\hline Substitution & 256 & $79.5 \%$ & 30 \\
Insertion & 39 & $12.1 \%$ & 20 \\
Omission & 27 & $8.4 \%$ & 20 \\
Total & 322 & $100 \%$ & 30 \\
\hline
\end{tabular}

substitution. On the other hand, insertion and omission of vowel letters were also found among Chinese students but with a relatively smaller frequency.

Three types of the spelling errors related to substitution of vowels were found. Firstly, Chinese students substituted long for short vowels and vice versa, such as * <กงสูล > for <กงสุล> /konsǔn/ "consul" and * <ปก > for <ปีก > / pìk/ "wing." Then, they also substituted one vowel letter with another representing a homophonic sound, such as *<หลงไหล> for <หลงใหล> /lǒnlăj/ "to be fascinated," *<สำพัน $>$ for <สัมพันธ์> / sămp ${ }^{\mathrm{h}}$ an/ "relations," and *<กรรม ไร> for <กำไร> / kamraj/ "profit." Vowel letters with similar sounds were also misused, such as: *<ปรับปรอง > for <ปรับปรุง > /pràppruy/ "adjust," * <งูห่อ > for <งูเห่า> /yu:hàu/ "cobra," and *<พร่ายหลาย> for <แพร่หลาย> / $\mathrm{p}^{\mathrm{h}} \mathrm{r} \hat{\mathrm{E}} \mathrm{l}$ lă:j/ "extensively." Moreover, insertion of vowel letters mainly occurred in vowels $<-$ e $>$ /o:/ and $<-$ ะ $>$ a/. When these two vowels are pronounced but unwritten, Chinese students tended to insert them, such as * <คณะบดี> for <คณบดี> / $\mathrm{k}^{\mathrm{h} a ́ n a ́ b s: d i: / ~}$ "dean" and *<ทอรมาน $>$ for $<$ ทรมาน $>/ \mathrm{t}^{\mathrm{h}}$ ว:ráma:n/ "torture." In addition, some Chinese students inserted $<-1>/ \mathrm{a} /$ when there is an /a/ sound, such as * <กรกาฎา คม > for <กรกฎาคม > /kàrákàda:k $k^{\mathrm{h}} \mathrm{om} /$ "July," which reflects that they are not sensitive to length of sounds. Finally, Chinese students also omitted vowel letters $<-$ ะ $>$ a/ and $<-1>$ /a:/ in some words, such as, ${ }^{*}<$ สดวกสบาย $>$ for $<$ สะดวกสบาย $>$ | sàdùaksàba:j/ "convenient" and *<สมัคคี > for <สามัคคี> / să:mákk $k^{\mathrm{h} i}$ / "harmony."

\subsubsection{Spelling Errors in Initial Consonant Letters}

Chinese students made 178 spelling errors in initial consonant letters, including both errors in single initial consonant letters and initial consonant clusters. The substitution errors account for an absolute predominant percentage of all the errors. As for omission and insertion, they are much more infrequent, and only some scattered errors were recorded.

In terms of substitution of initial consonant letters, Chinese students were likely to substitute one initial consonant letter with another representing the 
TABLE 3 Spelling errors in initial consonants letters classified by how initial consonant letters were misspelled

Patterns of spelling errors Frequency Percentage Participants

\begin{tabular}{lrcr}
\hline Substitution & 174 & $97.8 \%$ & 29 \\
Omission & 3 & $1.7 \%$ & 3 \\
Insertion & 1 & $0.5 \%$ & 1 \\
Total & 178 & $100 \%$ & 30 \\
\hline
\end{tabular}

same sound, such as *<อณุมัติ> for <อนุมัติ> /Rànúmát/ "approve" and *<เสร้า โสก> for <เศร้าโศก> /sâusòkk/ "depressed." They also substituted voiceless for voiced initial consonants and vice versa, such as *<อตีด> for <อดีต> /Ràdì:t/ "former" and *<บัจจุบัน> for <ปัจจุบัน> /pàtcùban/ "present." The substitution of $\langle\boldsymbol{s}\rangle / \mathrm{r} /$ for $<$ ล $>/ \mathrm{l} /$ and vice versa were also seen, such as * $<$ เรียนแบบ $>$ for <เลียนแบบ> /lianbغ̀:p/ "copy" and *<กำไล> for <กำไร> /kamraj/ "profit." Then, they substituted low-class for high-class initial consonants and vice versa, such as *<ลำไซ่> for <ลำไส้> /lamsâj/ "intestine" and *<สามัคขี> for <สามัคคี $>$ | sǎ:mákk ${ }^{\text {hi: }}$ / "harmony." Finally, the substitution of $<$ ล $>/ \mathrm{l} /$ for $<$ น $>/ \mathrm{n} /$ was also seen, such as *<แล่นแฟ้น> for <แน่นแฟ้น> /nê:nfé:n/ "firmly." A small number of omissions and insertions was also recorded. Three spelling errors were related to the omission of initial consonant letters: *<ลงไล> and *<ลงใหล $>$ for <หลงใหล> /lǒnlăj/ "to be fascinated," in which the unpronounced leading consonant letter $<$ ห $>/ \mathrm{h} /$ was omitted. Only one spelling error of insertion was found among initial consonant letters, which was *<สับประรด $>$ for $<$ สับปะรด> /sàpàrót/ "pineapple." In this case, the Chinese student inserted $a<\delta>/ r /$ in the second syllable of the word.

\subsubsection{Spelling Errors in Final Consonant Letters}

Spelling errors in final consonants are the third most spelling errors made by Chinese students. 175 spelling errors were found, which presents 20.4 percent of the total spelling errors. Most of the spelling errors in final consonants were substitution whereas the errors in insertion and omission are rarely seen.

The spelling errors in substitution of final consonant letters can be summarized into three groups: 1) substituting one final consonant letter with another representing a homophonic sound, such as *<โอกาศ> for <โอกาส>/Ro:kà:t/ "chance" and *<รำคาน> for <รำคาญ > / $\mathrm{ramk}^{\mathrm{h}}$ an/ $/$ "to be annoyed"; 2 ) substituting one final consonant letter with another representing a similar sound, such 
TABLE 4 Spelling errors in final consonant letters classified by how final consonant letters were misspelled

Patterns of spelling errors Frequency Percentage Participants

\begin{tabular}{lrcr}
\hline Substitution & 171 & $97.8 \%$ & 30 \\
Insertion & 2 & $1.1 \%$ & 2 \\
Omission & 2 & $1.1 \%$ & 2 \\
Total & 175 & $100 \%$ & 30
\end{tabular}

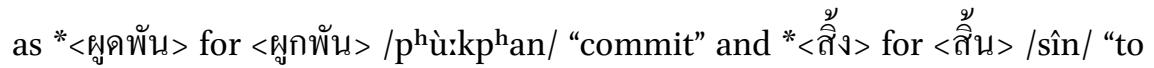
be finished"; 3) other irregular substitution of final consonants, such as *ผผลิต ภัฑณ์ $>$ for < ผลิตภัณฑ์> / $\mathrm{p}^{\text {hàlittà }} \mathrm{p}^{\mathrm{h}} \mathrm{an} /$ "product" and * <สะดวนสบาย> for <สะดวก สบาย> / sàdùaksàbaij/ "convenient." Two spelling errors were errors in the omission of final consonants letters, which are *<ประสบกาณ์ $>$ for $<$ ประสบการณ์ $>$ / pràsòpka:n/ "experience" and *<แน่แฟ้น> for <แน่นแฟ้น> /nê:nfé:n/ "firmly." In the two examples here, the front nasal final sound /n/ was omitted. Two insertion spelling errors in final consonant letters were made. The first was the insertion of $<ง>/ \mathrm{y} /$ in the word $<$ แต่ $>/ \mathrm{t} \dot{\mathrm{z}} /$ "but" and the second one is * $<$ มาก> for $<$ มา $>/ \mathrm{ma}$ / "come," in which a $<\mathrm{n}>/ \mathrm{g} /$ was inserted in the correct word.

\subsubsection{Spelling Errors in Unpronounced Letters}

According to Table 5, over half of the spelling errors in unpronounced letters were omission. The spelling errors in substitution and insertion were nearly the same, which take up 25.8 percent and 23.9 percent respectively.

Omission of unpronounced letters can be allocated into three groups; namely, omitting unpronounced consonant letters with a sound-killing

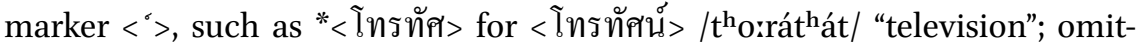
ting unpronounced consonant letters without a sound-killing marker, such as *<สามาถ> for <สามารถ> / să:mâ:t/ "can"; and omitting unpronounced vowel letters, such as *<ประวัต> for <ประวัติ > /pràwàt/ "history." Substitution of unpronounced letters only appears in marked unpronounced consonant letters. Chinese students randomly chose another consonant letter to replace the right one, for example, *<ศัพร์>, *<ศัพน์>, and *<ศัพย์> for <ศัพท์> / sàp/ "vocabulary." Insertion of unpronounced letters could be found in both marked unpronounced consonant letters and unpronounced vowel letters, for example, *<ผูกพันธ์> for < ผูกพัน> / $\mathrm{p}^{\mathrm{h} u ̀ v k p h a n / ~ " c o m m i t " ~ a n d ~ *<ส ั ง เ ก ต ุ>~ f o r ~<ส ั ง เ ก ต>~}$ /săykèrt/ "observe." 
TABLE 5 Spelling errors in unpronounced letters classified by how unpronounced letters were misspelled

\begin{tabular}{lccc}
\hline Patterns of spelling errors & Frequency & Percentage & Participants \\
\hline Omission & 78 & $50.3 \%$ & 26 \\
Substitution & 40 & $25.8 \%$ & 25 \\
Insertion & 37 & $23.9 \%$ & 25 \\
Total & 155 & $100 \%$ & 30 \\
\hline
\end{tabular}

TABLE 6 Spelling errors in tone markers classified by how tone markers were misspelled

\section{Patterns of spelling errors Frequency Percentage Participants}

\begin{tabular}{lrcc}
\hline Insertion & 9 & $47.4 \%$ & 9 \\
Omission & 8 & $42.1 \%$ & 7 \\
Substitution & 2 & $10.5 \%$ & 2 \\
Total & 19 & $100 \%$ & 11 \\
\hline
\end{tabular}

\subsubsection{Spelling Errors in Tone Markers}

Nineteen spelling errors in tone markers were made by eleven Chinese students, which included: insertion, omission, and substitution, as can be seen in Table 6 .

Including the low tone marker, falling tone markers, and rising tone marker, they were all inserted by Chinese students, such as *<เครี่ยด $>$ for $<$ เครียด $>$ / $\mathrm{k}^{\mathrm{h}}$ rîat/ "serious," *<น้อก > for <นอก > / nô:k/ "outside," and *<ต๋อนนี้> for < ตอนนี้> /to:nní:/ "now." On the other hand, both the low and falling tone markers were omitted by Chinese students, such as * <อยาง> for < อย่าง> /jà:y/ "how" and *<ดัง เดิม> for <ดั้งเดิม> / dândr:m/ "traditional." Finally, only two spelling errors are substitution of tone markers: *<กว่าง> for <กว้าง> /kwây/ "widely" and *<แม่ แต่> for <แม้แต่> /métè/ "even."

3.1.6 Other Spelling Errors

Another ten misspelled words were also found but they could not be grouped into the types presented above. Therefore, they are listed separately in Table 7 . 
TABLE 7 Other spelling errors

\begin{tabular}{|c|c|c|}
\hline Misspelled words & Correct words & Meaning \\
\hline *พาเชิญ, * พะเชิญ & เผชิญ /phàt $c^{\mathrm{h}} \gamma: n /$ & confront \\
\hline *สเหน่ & เสน่ห์ /sànè:/ & charm \\
\hline *เคิย & เคย $/ \mathrm{k}^{\mathrm{h}} \gamma \mathrm{ij} /$ & once \\
\hline *วัฒนธรม, *วัฒนธรรรม & วัฒนธรรม / wátthánátham/ & culture \\
\hline$*_{\ell}$ & อยู่ /jù:/ & exist \\
\hline *ก้อ & ก็ /k̂̂:/ & also \\
\hline *ศัพ์ & ศัพท์ /sàp/ & vocabulary \\
\hline *เก็บ & เก็บ /kèp/ & keep \\
\hline
\end{tabular}

\subsection{Causes of Spelling Errors in Thai made by Chinese Students}

There are five causes of spelling errors made by Chinese students: 1) irregularities in the Thai language; 2 ) interference from the Chinese phonological system; 3) carelessness in writing; 4) differences between the Chinese and Thai writing systems; 5 ) influences from native speakers of Thai.

\subsubsection{Irregularities in the Thai Language}

The first cause of the spelling errors made by Chinese students is the existence of irregularities in the Thai language. The biggest irregularity is that many sounds can be represented by several letters including: vowel letters, initial consonant letters, and final consonant letters. For example, in the vowel sys-


can be represented by $<-$ รร $>$ and $<น<>$ / $/ \mathrm{am} /$ sound is corresponding to $<-$ รรม $>$, <ㄱ> and <ัม > (Thonglor 2012: 150-154). Many initial consonant sounds can also be represented by different letters, such as the high-class sound $<\mathrm{s}>$ has three letters to represent it, namely, $\langle\pi>,<\mathrm{Y}\rangle$, and $\langle\uparrow>$. Likewise, 33 consonant letters are employed to represent six final sounds, ${ }^{3}$ which means that one final sound is corresponding to several different letters, such as final sound $<t>$ can be represented by sixteen different consonant letters. More than one graphic representation of sounds caused Chinese students to substitute vowels, initial consonants, final consonants with other letters representing a homophonic

3 As claimed by Danvivathana (1981: 192), there are six final consonants in Thai: three close final sounds /-k/, /-t/, /-p/ and three open final sounds /-n/, /-n/, /-m/. The two diphthong endings $/ \mathrm{u} /$ and $/ \mathrm{j} /$ are not included here. 
sound, such as: *<หลงไหล > for <หลงใหล> /lǒylăj/ "to be fascinated," *<ไพสาล> for < ไพศาล > /phajsǎin/ "vast," and *<สังเกษ> for < สังเกต > / sănkèrt/ "observe."

Another obvious irregularity that caused spelling errors among Chinese students was the existence of unpronounced letters, which could either be unpronounced consonant letters under a sound-killing marker $\stackrel{\delta}{<}>$ such as $\left\langle\eta^{\prime}>\right.$ in <ศัพท์> / sàp/ "vocabulary," or those without any marker such as <ร > in <สามารถ> /sǎ:mâ:t/ "can" and <ุ> in <ธาตุ> / thâ:t/ "element." Those unpronounced letters caused Chinese students to omit necessary letters, substitute incorrect letters for correct ones, and insert redundant letters, such as: *<มอเตอร์ไซต์> for <มอเตอร์ไซค์> /mว:tr:saj/ "motorcycle," *<ปราถนา> for <ปรารถนา> / prà:tthànă:/ "desire," or *<อนุญาติ> for <อนุญาต> /Rànújâ:t/ "allow."

Moreover, various initial consonant clusters in Thai also caused some spelling errors, including: substituting $<ซ>/ s /$ for $<$ ทร $>/ \mathrm{s} /$, such as ${ }^{*}<ซ า ย>$ for <ทราย> /sa:j/ "sand," omitting the silent leading consonant <ห>/h/, such as *<ลงใหล > for <หลงใหล> /lǒnlăj/ "to be fascinated," inserting a redundant consonant letter to form a true cluster, such as * <สับประรด $>$ for $<$ สับปะรด $>$ | sàppàrót/ "pineapple," or inserting an unnecessary vowel $<-$ \& $>$ /a/ or $<-0>\mid$

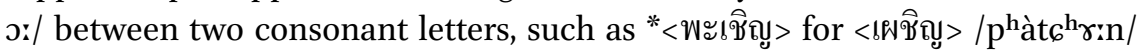
"confront" and *<คณบอดี> for <คณบดี> /khánábərdi: "dean."

Other than the spelling errors made by Chinese students, they seemed to not be fully competent with the complex tone system of the Thai language. They inserted redundant tone markers, omitted necessary tone markers, or substituted tone markers with incorrect ones, such as *<แซ่กแซง > for <แทรกแซง > |

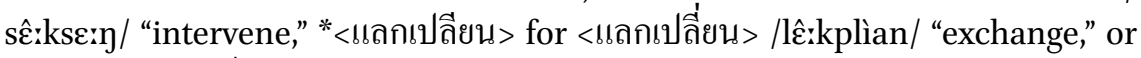
*<กว่าง > for <กว้าง> /kwâ:y/ "widely." Additionally, the ambiguity in tones also caused Chinese students to substitute low-class for high-class initial consonant letters and vice versa, such as *<พูกพัน $>$, * <ภูกพัน $>$ for $<$ ผูกพัน $>/ \mathrm{p}^{\mathrm{h}}$ ùk $k p^{\mathrm{h}}$ an/ "associate" and *<สามัคขี> for <สามัคคี> / sǎ:mákk $\mathrm{k}^{\mathrm{h}} \mathrm{i}$ / "harmony."

Since Thai vowels are not always written in the consonant-vowel linear order, some of them have to be put before initial consonants, such as $\langle\measuredangle b->|\varepsilon:|$ and $<$ ไ-> /aj/, which are called "misaligned vowels" by Winskel (2009:2). When vowels are put before an initial consonant, the order of spelling will be vowel + initial consonant + final consonant (if any); however, the order of pronunciation is still initial consonant + vowel + final consonant (if any). Therefore, a mismatch between spelling and pronunciation occurs. When misaligned vowels are spelled with initial consonant clusters, Chinese students tend to make spelling errors like *<สเหน่> for <เสน่ห์> /sànè:/ "charm" and *<พะเชิญ> for <เผชิญ > / hà $^{\text {th }}{ }^{\text {hr:n }}$ / "confront."

Finally, a Chinese student misspelled *<เคิย $>$ for $<$ เคย $>/ \mathrm{k}^{\mathrm{h}}$ : $\mathrm{j} /$ "ever" due to the overgeneralization regarding the occurrence of the vowel $/ \gamma$ : / with the final 
consonant sounds in Thai; i.e., $/ \mathrm{p} /, / \mathrm{t} /, / \mathrm{k} /, / \mathrm{m} /, / \mathrm{n} /, / \mathrm{y} /$, such as <เกิด> /kr̀:t/ "happen," <เกิน> / kr:n/ "far," and <เลิก> /lर्:k/ "stop." However, he simply overgeneralized such a rule to include cases like the two diphthong endings $/ \mathrm{u} /$ and


does not apply. As one vowel letter has different forms when spelled with different final consonants, the error *<เคิย> can also be categorized into the errors caused by irregularities in the Thai language.

\subsubsection{Interference from the Chinese Phonological System}

Articulation and spelling are closely connected when spelling an alphabetic language, as the spelling of alphabetic languages is based very much on sounds. It has been proven that spelling errors can be traced back to errors in speech to some extent (Groff 1973; Bancha 2013; Grigonite and Hammarberg 2014).

Chinese and Thai differentiate greatly in terms of their phonological systems, which might cause misarticulation among Chinese students when speaking Thai. Firstly, Chinese students' dialects also play an important role in their Thai spelling. For example, only the students who speak Southwestern Mandarin $^{4}$ substituted <ล> / / for <น> /n/, such as *<ชัยชละ > for <ชัยชนะ> / t6 ${ }^{\mathrm{h}}{ }^{\mathrm{ajt}} 6^{\mathrm{h}}$ áná/ "victory." It is because the $/ \mathrm{n} /$ sound and / $/$ sound in Southwestern Mandarin do no distinguish semanteme (Sun 2011: 132). In other words, the people who speak Southwestern Mandarin the meaning of the words will not be different if the $/ \mathrm{n} /$ sound and $/ \mathrm{l} /$ sounds are interchanged. Therefore, they often confound these two sounds when speaking foreign languages, such as English and Thai. Only Chinese students who speak the Jin dialect ${ }^{5}$ made spelling errors in $\langle แ b->/ \varepsilon$ : /, such as *<สาน $>$ for $<$ แสน $>$ /š̌:n/ "hundred thousand." It is because there is no /a:n/ sound in Jin dialect and they tend to use / $\varepsilon: n /$ to replace it, which makes them have big problems in distinguishing / $/ \mathrm{m}$ / and /a:n/ when speaking other languages ( $\mathrm{Li}$ 2006: 118). Only the Chinese students who speak the Jin dialect and Jilu Mandarin substituted the velar nasal final sound for the labiodental nasal final sound, such as *<กลิ่ง > for < กลิ่น > / krìn/ "smell." As stated by Zee (1985) and Hou (2015), people from the northern part of China generally have stronger velar nasal sounds in their dialects, especially among Jin dialect speakers, who do not have alveolar nasal sounds $/ \mathrm{n} /$ in their dialect at all, so they transfer these nasal sounds when speaking other languages, such as Mandarin Chinese and English.

4 Southwestern Mandarin is spoken by the people who live in southwestern part of China, it is the most widespread Chinese dialect.

5 Jin dialect is spread around the north of Shaanxi Province, most parts of Shanxi province, and the Mideast part of Inner Mongolia Autonomous Region. 
Moreover, some differences between Chinese and Thai phonology also cause misarticulation among Chinese students, which further brought about some spelling errors. Firstly, there is no difference between voiced consonants and voiceless consonants in Chinese. As a result, they substituted voiced for voiceless consonants and vice versa, such as * <บัจจุบัน> for <ปัจจุบัน > /pàtcùban/ "present" or *<ปะหมี่> for <บะหมี่> /bàmì:/ "noodle." They also substituted <ร> $/ \mathrm{r} /$ for $<\mathrm{a}>/ \mathrm{l} /$ and vice versa since there is no trill in Chinese phonology. Secondly, Chinese students have big problems in grasping the differences between long and short vowels accurately since there is no duration difference between Chinese vowels which caused them to make the errors such as *<ชีวิตชีวะ > for <ชีวิตชีวา> / t $^{\mathrm{h}}{ }_{\text {i: }}$ íttgh $^{\mathrm{h}}$ i:wa:/ "life." Moreover, the deviated pronunciation of Chinese students in Thai was also reflected in the six back vowel sounds: i.e.,

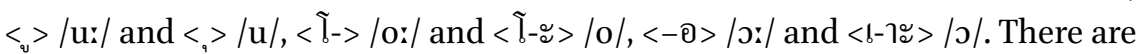
only $/ \mathrm{u} /$ and $/ \mathrm{o} / \mathrm{used}$ as back vowels in Chinese, whereas Thai has six. The misarticulation of Chinese students in pronouncing the six Thai back vowels made them commit a large number of spelling errors, such as * <กุงสล > for <กงสุล> /koysǔn/ "consul," *<โมเตอร์ไซ> for <มอเตอร์ไซค์> /mə:tr:saj/ "motorcycle," or * $<$ ประสอบการณ์> for <ประสบการณ์> / pràsòpka:n/ "experience." Finally, the three word final stop consonant sounds $/ \mathrm{k} /, / \mathrm{t} /$, and $/ \mathrm{p} /$, which do not exist in the Chinese phonological system, were also misused by Chinese students, such


"refuse."

\subsubsection{Carelessness in Writing}

In particular, the complicated Thai writing system calls for great attention otherwise spelling errors will be committed easily. A small number of spelling errors made by Chinese students were caused by students' carelessness. For example, in the word <วัฒนธรรม> / wátthánátham/ "culture," two kinds of wrong form were found: * >วัฒนธรรรม > and *<วัฒนธรม >. Actually, the student already spelled the word <วัฒนธรรม> correctly in the previous content. As a result of carelessness, they inserted and omitted $\mathrm{a}<\boldsymbol{\delta}>/ \mathrm{r} /$. Carelessness also caused final consonant insertion. In the sentence: <เพราะผม*มากจากประเทศ จีน $>/ \mathrm{p}^{\mathrm{h}}$ róp $^{\mathrm{h}}$ ǒmmâ:ktca:kpràt ${ }^{\mathrm{h}} \mathrm{e}$ :ttci:n/ "because I come from China," the writer inserted a $<\mathrm{n}>/ \mathrm{k} /$ in the word $<$ มา $>/ \mathrm{ma}$ / "come." The spelling error might be caused by carelessness since the word $<$ มา $>$ is a basic word and its meaning and pronunciation should not have any ambiguity for Chinese students. The only explanation for the error is that the writer made a slip of the pen when spelling. Likewise, errors like *<ผลิตภัฑณ์> for <ผลิตภัณฑ์> /pàlittàphan/ "product" or * <ประสบกาณ์> for <ประสบการณ์ > / pràsòpka:n/ "experience" could also be explained by carelessness in writing. 


\subsubsection{Differences Between the Chinese and Thai Writing System}

Based on how spoken language is represented, writing systems of the world's languages can be classified into three types:1) alphabetic languages, representing spoken language by letters; 2) syllabary writing systems, using syllables to represent spoken language; 3) logographic languages, choosing characters to represent spoken language (Wang, Koda, and Perfetti, 2003: 130). Based on this classification, the Thai language is an alphabetic language since its spelling is based on sounds; whereas Chinese is classified as a logographic writing system because Chinese selects characters to represent its spoken language. The great differences between the Chinese and Thai writing systems also caused some spelling errors among Chinese students.

At first, Chinese students made some errors which did not meet the basic orthographic rules in Thai. For example, in the misspelled word * <ศัพ์> for <ศัพท์>/sàp/ "vocabulary," the writer added a sound-killing marker in the final consonant of the word, which makes the misspelled word deviate dramatically from the basic structure of a Thai syllable. Another example is $*<$ เก บ $>$ for <เก็บ $>$ /kèp/ "keep." Obviously, the high tone marker $\langle$ " $\rangle$ and vowel

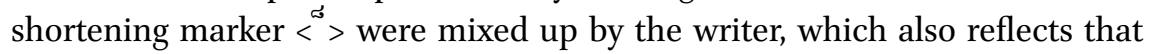
Chinese students are not fully competent to use various markers to present sounds.

\subsubsection{Influences from Thai Native Speakers}

As communication between Chinese students and Thai native speakers becomes more frequent, Chinese students have more opportunities to learn Thai from native speakers, especially from younger generation Thai speakers via the internet. Actually, some language habits and words used by young Thais are informal and only appear in their spoken language. However, Chinese students, as foreign language learners, do not have an adequate understanding of them.

Judging from this, spelling errors like * $<$ ก้อ $>$ for $<$ ก็ $>/ \mathrm{k} \hat{\mathrm{x}} / /$ "also" and $*<$ ยุ $>$ for <อยู่> /jù:/ "exist," can be attributed to influence from interaction with Thai native speakers. It is because Thai native speakers reduce some words for convenience but only use them in informal occasions, such as chatting with friends or posting content on social applications. Some Chinese students tend to imitate this way of spelling words because it is regarded as being native.

To summarize, among the five causes mentioned above, irregularities in the Thai language caused the most spelling errors, more than sixty percent of the spelling errors can be traced back to incompetence among Chinese students when confronted with various irregularities in the Thai language, as shown in 
Irregularities in the Thai language

Interference from the Chinese phonological system

Carelessness in writing

Differences between the Chinese and Thai writing system

Influence from Thai native speakers

Total

525

324

5

3

2

859
$61.1 \%$

$37.8 \%$

$0.6 \%$

$0.3 \%$

$0.2 \%$

100

Table 8. Interference from the Chinese phonological system caused the second most spelling errors, accounting for 37.8 percent of the spelling errors. Apart from that, carelessness in writing, differences between the Chinese and Thai writing system, and influences from native speakers were also taken into account since these factors also brought about some scattered errors among Chinese students.

\section{Conclusion}

The current paper sheds light on spelling errors in Thai made by Chinese students speaking Thai as a foreign language. A composition writing and dictation task were conducted among thirty Chinese students who majored in Thai. In total, 859 spelling errors were found. According to the findings, Chinese students made the most spelling errors in writing vowel letters $(37.5 \%)$, then initial consonant letters $(20.7 \%)$, final consonant letters $(20.4 \%)$, unpronounced letters $(18.0 \%)$, tone markers $(2.2 \%)$, and others $(1.2 \%)$ respectively. In terms of causes of spelling errors, various irregularities in the Thai language caused more than half of the spelling errors, including multiple graphic representations of sounds, unpronounced letters, consonant clusters, and etc. Additionally, interference from the Chinese phonological system was another main cause of spelling errors, which brought about 37.8 percent of the errors found. Both students' dialects, and some differences between both the Chinese and Thai phonological systems were transferred by Chinese students when spelling Thai. Apart from that, the carelessness of students, differences between the Chinese and Thai writing systems, and influence from native speakers of Thai, 
were also sources of errors that should be taken into consideration, because some scattered errors could be traced back to them.

\section{$5 \quad$ Pedagogical Implications}

The findings of the present study also provide some pedagogical implications. First, spelling errors should be viewed in a more positive way rather than simply being treated as slips of the pen. As an important feedback of learning, spelling errors should be identified and explained in order to find out the best way to correct and avoid them. Secondly, irregularities in the Thai language should be realized and emphasized in the process of learning Thai. More understanding of the properties of Thai can help Thai language learners improve their spelling skills effectively. Thirdly, many spelling errors are related to pronunciation. Clear pronunciation reflects speakers' high levels of proficiency in learning a foreign language. On the contrary, misarticulation not only affects the image of speakers, but is also a potential factor that might cause spelling errors.

\section{References}

Alhaisoni, Eid M., Khalid M. Al-Zuoud, and Daya Ram Gaudel. 2015. Analysis of Spelling Errors of Saudi Beginner Learners of English Enrolled in an Intensive English Language Program. English Language Teaching 8.3:185-192.

Bancha, Woralak. 2013. What Causes Spelling Errors of Thai EFL Students? Annual Review of Education, Communication \& Language Sciences 10: 107-129.

Bean, Wendy and Chrystine Bouffler. 1987. Spell by Writing. Sydney: Primary English Teaching Association.

Brosh, Hezi. 2015. Arabic Spelling: Errors, Perceptions, and Strategies. Foreign Language Annals 48.4: 584-603.

Danvivathana, Nantana. 1981. Thai Writing System. Doctoral Dissertation, University of Edinburgh.

Dich, Nadezda. 2011. Cross-Linguistic Study of Spelling in English as A Foreign Language: The Role of First Language Orthography in EFL Spelling. Doctoral Dissertation, Cornell University.

Ellis, Rod. 1994. The Study of Second Language Acquisition. Oxford: Oxford University. Gunion, Richard. 2012. What are The Types and Proportions of "Major" Spelling Errors Made by "Short-Stay" Japanese University Students Enrolled Full-Time at Newcastle 
University? Annual Review of Education, Communication \& Language Sciences 9: 15-41.

Groff, Patrick. 1973. Children's Speech Errors and Their Spelling. The Elementary School Journal 74.2: 88-96.

Grigonyte, Gintare and Björn Hammarberg. 2014. Pronunciation and Spelling: The Case of Misspellings in Swedish L2 Written Essays. Paper Presented at the 6th International Conference on Human Language Technologies-The Baltic Perspective (Baltic HLT), September 26-27, 2014, Kaunas, Lithuania.

Hou, Jing-Yi. 2015. The Study of Jin Chinese. Beijing, Chinese Social Science Press. (In Chinese)

Kim, Shin-Hye. 2001. An Error Analysis of College Students' Writing: Is that really Konglish? Studies in Modern Grammar 25: 159-174.

Li, Jian-Xiao. 2006. A Study of Phonology on Shanbei Jin Dialect. Doctoral dissertation, Beijing Language and Culture University. (In Chinese)

Mahmoud, Abdulmoneim. 2013. Spelling Errors of Arab Learners of E FL: A Two-Way Analysis. TESol Arabia Perspectives 20.1: 6-12.

Plaengson, Rungrudee. 2017. The Science of Teaching Thai as a Foreign Language. Bangkok: Chulalongkorn University Printing House. (In Thai)

Saville-Troike, Muriel. 2006. Introducing Second Language Acquisition. Cambridge University Press.

Sun, Yue-Chuan. 2011. Studies on Dialects of Southwestern Mandarin in Sichuan Province: Their Phonological Systems and Historical Development. Doctoral Dissertation, Zhejiang University. (In Chinese)

Thonglor, Kamchai. 2012. Fundamentals of the Thai Language. Bangkok: Ruamsarn. (In Thai)

Treiman, Rebecca and Margo Bowman. 2015. Spelling in African American Children: The Case of Final Consonant Devoicing. Reading and Writing 28.7: 1013-1028.

Wang, Min, Keiko Koda and Charles A. Perfetti. 2003. Alphabetic and Nonalphabetic L1 Effects in English Word Identification: A Comparison of Korean and Chinese English L2 Learners. Cognition 87.2: 129-149.

Winskel, Heather. 2009. Reading in Thai: The Case of Misaligned Vowels. Reading and Writing 22.1: 1-24.

Winskel, Heather and Kanyarat Iemwanthong. 2009. Reading and Spelling Acquisition in Thai Children. Reading and Writing 23.9: 1021-1053.

Zee, Eric. 1985. Sound Change in Syllable Final Nasal Consonants in Chinese.Journal of Chinese linguistics 13.2: 291-330. 